
(1)

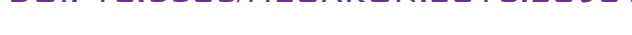

\title{
Children's Views about Child Friendly City: A Case Study from Izmir
}

\author{
Çocukların Çocuk Dostu Kent Hakkında Görüşleri: İzmir Örneği
}

\author{
Hikmet GÖKMEN, Burcu Gülay TAŞÇı
}

\section{ABSTRACT}

Due to the effects of industrialization, urbanization, and the corresponding environmental degradation of this century, children cannot be sufficiently involved in urban life. A good city is child-centered and child friendly in all aspects. Recently, studies concerning the importance of child participation have been carried out in order to design child friendly cities. Within this context, this study sought the views of children about the city via research conducted in three different districts of Izmir. Open-ended questions and drawing tasks were among the tools used to obtain their opinions. The case study had two stages: The first stage was conducted in two schools within the central city of Izmir: one with a low socioeconomic profile, and other with high socio-economic data. There are no projects or future district municipality plans related to the issue of a child friendly city in the areas surrounding these schools. The aim was to examine the impact of socio-economic data on the perceptions of children. The second stage of the study took place in Seferihisar, a peripheral district outside the center of Izmir. Known for its vision of being a Slow City, Seferihisar Municipality considered the issue of being a child friendly city in its strategic plan and accomplished various related projects. The impact of municipal projects on the perceptions of children in a mid-level group were examined, irrespective of socio-economic status. Comparing and interpreting the results of this dual research on children's views about a child friendly city paves the way for an evaluation of children's views and will enable Izmir to take the first step to fulfilling the criteria of being a child friendly city. The findings of the study are important data for the future, and will be of interest to architects and planners, in particular.

Keywords: Child-friendly city; child-friendly environment; children's rights; Izmir-Turkey; participation.

ÖZ

Içinde bulunduğumuz yüzyılda endüstrileşme, tüketim, hızlı nüfus artışı, hızlı kentleşme ve paralelinde gelişen çevresel bozulmanın etkisi ile çocuklar kentsel yaşama yeterince katılamamaktadır. Oysa iyi bir kent çocuk merkezlidir; yani tüm açılardan çocuk dostudur. Son yıllarda kentlerin çocuk dostu tasarlanmasında çocuk katılımının öneminden bahseden çalışmalar yapılmaktadır. Bu bağlamda, bu çalışma da, İmir'de üç farklı ilçede gerçekleştirilen bir alan çalışması ile çocukların "çocuk dostu kent" hakkındaki görüşlerini almayı hedeflemektedir. Görüş almada araç olarak açık uçlu soru ve resim çalışmalarından faydalanılmıştır. Alan çalışması iki aşamalı olarak planlanmıştır. Birinci aşamada İzmir ili sınırları içerisinde yer alan düşük ve yüksek sosyo-ekonomik verilerine sahip iki okulda çalışılmıştı. Bu iki okulun bulunduğu ilçelerde belediyelerin "çocuk dostu kent konusunda henüz hiçbir çalışması ve gelecek planı bulunmamaktadır. Burada amaçlanan sosyoekonomik verilerin çocukların algısında etkisini araştırmaktır. Alan çalışmasının ikinci kısmında ise Izmir'de il sınırları dışında bir ilçe olan Seferihisar'da çalısıılmıştır. Sakin şehir vizyonu ile tanınan Seferihisar belediyesi "çocuk dostu kent" olma konusunu stratejik planı içine almış ve konu hakkında çeşitli çalışmalar yapmıştır. Bu bağlamda bu ilçede sosyo-ekonomik durumu gözetmeden orta düzey sed verilerine sahip bir okul ile çalışılarak belediyenin çalışmalarının çocukların algılarına etkisi araştırılmıştır. Tüm bu iki araştırmanın sonuçları karşılaştırılarak ve daha sonra birlikte yorumlanarak çocukların "çocuk dostu kent" konusundaki görüşleri ortaya çıkartılmıştır. Çocuk görüşlerinin değerlendirilmesi ile Izmir kentinin çocuk dostu kent kriterlerine uygun hale gelmesi konusunda ilk adım atılmışır. Çalışmanın sonuçlarının gelecek için özellikle mimar ve planlamacıları ilgilendiren önemli verileri barındırdığı düşünülmektedir.

Anahtar sözcükler: Çocuk-dostu kent; çocuk-dostu çevre; çocuk hakkı; izmir-Türkiye; katıım.

Department of Architecture, Dokuz Eylül University, Faculty of Architecture, İzmir, Turkey.

Article arrival date: November 04, 2015 - Accepted for publication: August 23, 2016

Correspondence: Hikmet GÖKMEN. e-mail: hikmet.gokmen@gmail.com

๑ 2016 Yıldız Teknik Üniversitesi Mimarlık Fakültesi - ๑ 2016 Yıldız Technical University, Faculty of Architecture 


\section{Introduction}

Today, children development is bound to face plenty of problems in the city. Particularly in industrialized and relatively-developed cities, children live in crowded, unsafe and polluted environments. Such environments only rarely offer children facilities for learning, playing and recreation. The phenomenon of play, which used to be developed rather freely and unorganized throughout the urban residential environments of high density, appears to be confined to past. Children are imprisoned at their houses or their friends' houses and playgrounds offered by commercial spaces. ${ }^{1}$ Different sections of the community cannot take equal benefit from urban amenities since rapid urbanization does not prevent, but deepen inequality. In other words, drowned in problems entailed by urbanization, our cities fail to encounter the needs, expectations and wishes of children and cannot offer such environments where the child can safely spend time. Yet, a good city is child-centered, i.e., it is Child Friendly from all aspects. Children, just as adults, hold the right to actively participate in the community. Seen as such, our cities fail to create many opportunities for children. ${ }^{2}$

According to the Convention on the Rights of the Child, every child has the inherent right to life, be protected and prompt decision on all actions irrespective of any difference. $^{3}$ The child has the right to grow up in a livable, secure and healthy urban environment without discrimination of any kind. Promoting better standards for child's life can only be possible by recognizing, understanding and realizing their rights. The Child Friendly city requires active interest in children and their lives. Child-friendliness can be achieved in cities not only through actions undertaken by local or national governments, but also with cooperation of children themselves, their families and all persons, agencies and institutions they are engaged with.

The approach of Child Friendly cities assumes thorough implementation of the Convention on the Rights of the Child. For this reason, the Child Friendly city guarantees the right of every young citizen to influence decisions about their city and express their opinion on the city they want. ${ }^{4}$

UNICEF's Initiatives for Child Friendly Cities and ${ }^{5}$ for Growing up in Cities ${ }^{6}$ carry out crucial studies on the subject. Similar initiatives in Canada, Australia and USA take active role in creation of Child Friendly environments as well. In 2001, European Network of Child Friendly Cities (EN CFC) is founded as a network to stimulation local implementation of the UN Convention on the Rights of the

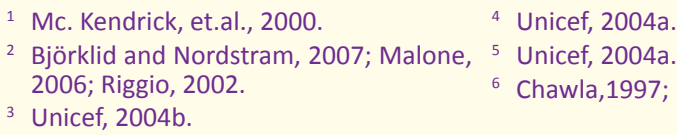

Child. This network has organized series of "Child in the City" conferences first held in Antwerp (Belgium) in 2002 followed by London (UK) in 2004, Stuttgart (Germany) in 2006, Rotterdam (Netherlands) in 2008, Florence (Italy) in 2010, Zagreb (Croatia) in 2012 and Odense (Denmark) in 2014. ${ }^{7}$

Secretariat of the Child Friendly City is established in 2000 as a common point of reference for both the Initiative and Movement of Child Friendly City. The Child Friendly Movement that was born in Italy is based on the principle of "participation" emphasized in the Convention. Aiming to reflect children's and young people's needs to make them become visible, the "Child Friendly City Movement" supports such implementation methods that improve the built environment. The Secretariat of Child Friendly City introduces best practices as well. ${ }^{8}$

In Turkey, having received its funding from the European Union, the "Child Friendly Municipality" project is carried out by the Association for Solidarity with the Freedom-Deprived Juvenile. It is held in cooperation with Çankaya Municipality in Ankara. ${ }^{9}$ In the same vein, the Turkish Child Friendly Initiative pursues various activities in 12 different provinces throughout the country (Antalya, Bursa, Tekirdağ, Kırşehir, Uşak, Gaziantep, Erzincan, Kayseri, Konya, Sivas, Trabzon, Karaman). The Child Friendly City can be deemed as a project realized by Turkish Republic and UNICEF for the period of 2006-2010 within the framework of national action plan. Financed by IKEA and UNICEF Turkish National Committee, UNICEF Turkish Branch has initiated the Child Friendly City project to provide support to municipalities in promoting Child Friendly policies and programs and creating Child Friendly spaces. Turkish Ministry of Interior, General Directorate of Civil Administration, Turkish Union of Municipalities, Middle East and West Asia Regional Headquarters of United Cities and Local Governments, and World Academy for Local Government and Democracy (WALD) all take part in national coordination of the Child Friendly City Project.

This project will be implemented by municipalities of Adana/Yüreğir, Ankara/Mamak, Bitlis, Giresun, İzmir/Bornova, Kırklareli/Lüleburgaz, Mersin, Şanlıurfa/Eyyübiye during the period of $2014-2015 .^{10}$

In addition to such municipal projects held, it is possible to address to the studies carried out in Turkey in two headings. The first group of the studies on the issue describes the Child Friendly City, its characteristics and example cities conceptually. The second group of studies ${ }^{11}$ is carried out by case studies. Istanbul ${ }^{12}$ is mostly selected as a study

\footnotetext{
7 http://www.childinthecity.com/

8 Unicef, 2004a.

9 http://www.ozgeder.org.tr

${ }^{10} \mathrm{http}: / /$ unicef.org.tr
}

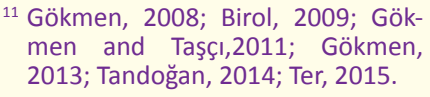

${ }^{11}$ Gökmen, 2008; Birol, 2009; Gökmen and Taşçı,2011; Gökmen, 2013; Tandoğan, 2014; Ter, 2015. 
area, but there are cases in the cities of Ankara ${ }^{13}$ and Ad$\mathrm{ana}^{14}$ as well. In these studies, observations and photographs served to define problem, while surveys with children and their parents are used to determine how much they see their environment as child friendly and to develop the proposals for more livable environments for children.

The thesis entitled" ${ }^{15}$ "Perception and Evaluation of the Environment of Children Live in Tarlabaşı" mentions the notion of the Child Friendly City and elaborates the case of Tarlabaşı, which is defined as one of the deprived areas in Istanbul city center. Techniques of observation, interview and survey are conducted in this area to define the problems. Despite all the problems they have, the children stated that they still want to live in this area reasoning mostly the existence of their dwelling there. This finding reveals that developing child friendly approaches is far more necessary.

Master thesis by Kirazoğlu ${ }^{16}$ entitled "Physical Environment - Child Relations, Outdoor Play Spaces and Criteria of Child-friendly Environment; Bakırköy \& Beylikdüzü Samples" and Kirazoğlu \& Akpınar's paper ${ }^{17}$ investigate outdoor playgrounds in Bakırköy and Beylikdüzü districts of Istanbul which have different housing typologies. These studies evaluate the existing situation of the outdoor playgrounds, which are used by children and should be designed with children. They also present proposals on integration and user accessibility of open public urban areas and children's parks with the city.

Tandoğan's dissertation ${ }^{18}$ entitled "Establishing Principles of Planning, Design and Management of Open Space for a 'Child Friendly City' in Istanbul" examines urban design objectives, which are one of the goals of the Child Friendly City concept for making the city more livable for the children. Küçük Ayasofya Neighborhood, Mass Housing Area and Kiptaş Salacak Housing Estate are three housing areas selected for the case study. Surveys with parents (who have a child aged between 5-14) and children (who are between 7-14) were conducted in these areas to define expectations and wishes of children concerning their physical environment and build up the environmental components of the Child Friendly City. Analyses of the housing areas on the basis of a Child Friendly Environment were also carried out and proposals were developed to make these areas more livable for children. Further, Tandoğan ${ }^{19}$ sets proposals for housing areas in the city center in her latter paper with reference to the case of Küçük Ayasofya Neighborhood given in her dissertation in 2011.

\footnotetext{
12 Güngör, 2002; Kirazoğlu, 2012; Kira- ${ }^{14}$ Özservet, 2016. zoğlu and Akpınar 2015; Özservet and 15 Güngör, 2002

Boz, 2015; Severcan, 2015; Tandoğan, ${ }^{16}$ Kirazoğlu, 2012.

2011; Tandoğan,2015; Tandoğan and

Ergun, 2013a; Tandoğan and Ergun,

2013 b.

${ }^{13}$ Koç, Tavşancıl and Demir, 2015.

17 Kirazoğlu and Akpınar, 2015.

18 Tandoğan, 2011.

19 Tandoğan, 2015.
}

Özservet's study ${ }^{20}$ examines the relationship between the child and the local administration through the case of Istanbul Esenler District Municipality. As a result of workshops with municipality employees, muhtars and children, Özservet highlights the importance of involving children in the process i.e. their participation on related topics as the first criteria for making the district child friendly.

Discussing the interaction of child-play, child-space and play-space from the eyes of children living in Esenler district, which is one of the most crowded and densest districts of Istanbul, Ayataç \& Genç's study ${ }^{21}$ evaluates the principles of urban planning and design. In this study, strengths and weaknesses of the neighborhood are determined via spatial and social analyses. The adopted methods included photograph description, focus group studies and surveys. In order to make evaluations from the eyes of a child, district-wide participatory workshops were held. In these workshops, evaluations and obtained results were based on the Child Friendly Environment principles "accessibility, use of the street, entertainment, socializing, security, physical environment, health, and diversity". Comparing the results of studies held with the children in Esenler district, evaluations were made in terms of making the district child friendly; substantial propositions were presented for Esenler Municipality, in specific and local administrations in general.

In a related paper, Severcan ${ }^{22}$ focuses on what the Child Friendly Place concept means for children living in Istanbul, and within this context, if the children consider their environment as child friendly or not. Views of children aged 9-11 and living in six different neighborhoods in Istanbul were obtained via conducting group interviews, mapping and neighborhood planning workshops. Using content analysis method and making reference to the study of Haikkola and Horelli, the author collected the children's definitions and determined that these definitions significantly match with the existing definitions in literature. Most of the children who took part in this study do not consider their environment child friendly due to lack of spatial and social facilities and problems of security and safety.

Within the framework of the international movement of Child Friendly Cities Initiative, Koç et al. ${ }^{23}$ determined how the children aged between 11-14 in Ankara perceive their city and what their positive and negative views regarding the city are. For this, the researchers conducted the survey "Ankara by the Child's View Survey". The positive and negative views of children living in Ankara comprised such issues as the cityscape; traffic, transportation, road and infrastructural works; boulevards and streets; green areas, playgrounds, entertainment and sports areas; social and

\footnotetext{
20 Özservet and Boz, 2015

${ }^{21}$ Ayataç and Genç, 2015.
} 
cultural facilities; human relations and attitude towards children; street children, homeless and handicapped individuals; security; pets and street animals. The views of children function as a guide on the subject of enhancing life standards of the city of Ankara.

Analysis of all these publications shows that a Child Friendly City aims to involve youngsters and children to take active part in decision making and express their wishes and opinions about their cities. In this sense, the focus of this study is on the views of children for the "Child Friendly City" in three different districts of Izmir in this study. Before getting into the details of the case studies, it is necessary to draw a conceptual framework for the issue of the Child Friendly Environment.

\section{Theoretical framework for Child Friendly Environment}

In recent times, such urban problems as traffic density causing noise and air pollution or social problems appear to have negative impact on mobility of children, lessening their use of outdoor space. Parents are rather worried about such challenging circumstances. Their concern results in bringing limitations to how and where children move and behave. ${ }^{24}$ There also are studies stating that breakdown of health or obesity in children is very much linked to this issue. ${ }^{25}$ The best way to overcome this challenge is to have outdoor playgrounds in proximity to dwellings. Physical activities follow creation of such facility areas per se, if provided.

Independent mobility is of great developmental value to children, because it helps them orient themselves and feel integrated with the environment, while creating the basis for environmental conceptualization and the construction of adequate cognitive maps. Environmental competences enhance the building of a sense of trust and independence. ${ }^{26}$ Mobility remains a critical point of departure in spatial awareness and development of activities children are involved. ${ }^{27}$

Lifestyle and living conditions of parents also influence children's freedom of movement. Parents carry children to different places and activities not mostly on foot, but by car. Yet, those parents who wish to encourage their children should allow them to interact with the environment and discover the surrounding by them. They should share their experience and sometimes, even take active part in it. ${ }^{28}$ Concerning the use of space by children in time, playing outside appears to have lost its luster. In 1950s and 1960 s, children used to play outdoors at any time of the day. There was only one type of childhood, the traditional

${ }^{24}$ Holloway and Valentine, 2000.

${ }^{25}$ Spencer and Woolley, 2000.

${ }^{26}$ Björklid \& Nordstram, 2007.

${ }^{28}$ Prezza, 2007; Rissotto and Giuliani, 2006. childhood of outdoor children. Over time, there were additionally two new types, namely indoor children and children of the backseat generation. ${ }^{29}$

The participation of children and youth in the shaping their settings plays a crucial role in the creation of child friendly environments..$^{30}$ Though one of the most important dimensions of citizenship, participation is a rather neglected phenomenon in many countries. Based on analysis of drawings, photographs and models, the results of Horelli's ${ }^{31}$ study on participation of children in Finland, Switzerland and France (Table 1) indicate how children are quite aware about the problems they have with their environment.

Horelli ${ }^{32}$ relates the children-environment interaction with social psychology and sociology. In this vein, Horelli has constructed the theoretical framework of "Environmental Child Friendliness". As a multi-dimensional and multi-level concept, "environmental child friendliness refers to settings and supportive environmental structures. Thus, children can construct and implement their goals or projects. The core dimensions for Horelli are not only urban and environmental qualities, but also basic services, security, family and relations with friends. The environment shaped by ten criteria makes up the living environment as a whole.

Horelli defines the environmental child friendliness in terms of the ten criteria mentioned below (Table 2).

Another study on "environment and the child" is based on an assessment and comparison of two similar suburban neighbourhoods with different styles of urban planning in Pihlajamäki (Helsinki, Rome) and Monte Mario (Rome, Italy). Having explored the interpretations of children living in these neighbourhoods as well as their mothers or fathers, elderly people and professionals, the study evaluates ten dimensions of environmental child-friendliness. At the same time, it analyzes children's views, opinions and demands from their neighbourhoods and the ideal environment. ${ }^{33}$ In case of Pihlajamäki, children described the most important qualities of the neighbourhood as recreational services, public areas, the social environment and the safety it provides. One group of children appreciated the playgrounds, sports facilities and the youth center, while another liked the familiarity of the neighbourhood, friends and the social security it provides. Since buildings were located not too close to each other, children also liked openness of the built environment and the surrounding nature and the opportunities for outdoor activities. They also emphasized the friendliness and familiarity. The dislikes,

\footnotetext{
${ }^{29}$ Karsten, 2005.

${ }^{30}$ Moore, 1990; Hart, $1992 . \quad \quad{ }^{33}$ Haikkola et.al., 2007.

${ }^{32}$ Horelli, 2007.
}

${ }^{31}$ Horelli, 1998. 
Table 1. A Summary of the case study results (Horelli, 1998, 234-235)

\begin{tabular}{|c|c|c|c|}
\hline Features & Kitee Finland & Locarno Switzerland & Darnetal France \\
\hline \multirow[t]{6}{*}{ Problems } & Dangerous traffic spots. & Too much traffic. & Dangerous traffic. \\
\hline & & Too much noise and pollution. & Too much litter. \\
\hline & Ugly buildings and yards. & & Ugly yards. \\
\hline & $\begin{array}{l}\text { Too little play equipment and } \\
\text { spaces for play and sports. }\end{array}$ & Too few spaces for play and sports. & $\begin{array}{l}\text { Not enough space for } \\
\text { play and sports. }\end{array}$ \\
\hline & Too few meeting places & Lack of community. & Lack of communal spaces. \\
\hline & for young and old. & & Drugs. \\
\hline \multirow[t]{7}{*}{ Content of solutions } & Flowers, trees. & & Greenery. \\
\hline & Play equipment. & Play equipment. & Play equipment. \\
\hline & Sport areas. & Sport areas. & Sport areas. \\
\hline & Traffic solutions. & Traffic solutions. & Traffic solutions. \\
\hline & A public "living room". & A community building. & \\
\hline & Theatres and cinemas. & & Museums, cinemas. \\
\hline & A cafe at the lakeshore. & & Better maintenance. \\
\hline Scale of planning & $\begin{array}{l}\text { From the schoolyard to the } \\
\text { neighbourhood. }\end{array}$ & The neighbourhood. & $\begin{array}{l}\text { The blocks around the } \\
\text { school. }\end{array}$ \\
\hline \multirow[t]{3}{*}{ Content of learning } & $\begin{array}{l}\text { The design schoolyards and } \\
\text { traffic solutions. }\end{array}$ & $\begin{array}{l}\text { To understand the area from } \\
\text { a less egocentric perspective. }\end{array}$ & $\begin{array}{l}\text { To see the dangers of the } \\
\text { area. }\end{array}$ \\
\hline & $\begin{array}{l}\text { To see the neighbourhood } \\
\text { with new eyes. }\end{array}$ & To use plans. & $\begin{array}{l}\text { To understand some steps } \\
\text { of planning. }\end{array}$ \\
\hline & Collaboration. & $\begin{array}{l}\text { The difficulty to change the } \\
\text { status quo. }\end{array}$ & $\begin{array}{l}\text { Problems with getting } \\
\text { things done. }\end{array}$ \\
\hline $\begin{array}{l}\text { Children's attitude } \\
\text { toward planning }\end{array}$ & $\begin{array}{l}97 \% \text { favourable, most children } \\
\text { like to continue. }\end{array}$ & $\begin{array}{l}99 \% \text { liked the planning, and } \\
78 \% \text { would like to continue. }\end{array}$ & $\begin{array}{l}78 \% \text { liked the experiment } \\
\text { and would like to do it again. }\end{array}$ \\
\hline
\end{tabular}

on the other hand, were concentrated to the small shopping center and its pubs where marginalized people with alcohol and other social problems spend time. Children mentioned the shopping center and the scary behaviour of people as the main problem of the neighbourhood. Perceived dangers and fears control and limit children's ability to move freely in the area. The interesting point is that it is neither traffic nor other clear physical dangers that limit children's ability to move, but that children seemed to limit their own movement because of social fears. ${ }^{34}$

In case of Monte Mario, the Roman children liked green areas and basic services the most. Green areas were appreciated by children for the possibility of playing group sports outdoors, seeing friends, getting together, playing, socializing, having fun and passing time in the open air without cars. The other pleasurable aspect of the neighbourhood was the presence of recreational, educational and commercial services. Proximity of these facility areas

${ }^{34}$ Haikkola et.al., 2007. to dwellings was mentioned as another issue. Spaciousness in relation to the size of open areas and home was appreciated as another aspect of the neighbourhood. The least liked elements in the area were the traffic and urban decay. According to replies of the children, traffic was closely connected to air pollution and reduction of independent mobility. Concerning the things children would like to, but do not, have in the area are listed as recreational services and public spaces that are equipped for games, a neighbourhood where they can breathe with fewer cars and more bike paths, and green areas where they can stay and play freely. The children also demanded that the use of streets, then full of cars, be given back to them. ${ }^{35}$

In result, children appreciated and demanded almost the same things in both cities. Finnish children mostly mentioned recreational services, family, friends, the community, the characteristics of the built environment and green areas. As for the Italian children, they placed impor-

${ }^{35}$ Haikkola et.al., 2007. 
Table 2. Normative dimensions and definitions of a Child Friendly environment (Horelli, 2007, 271; Nordström, 2009, 516)

\begin{tabular}{|c|c|}
\hline Normative dimensions & Abstract definitions \\
\hline \multirow[t]{2}{*}{ 1. Housing and dwelling } & - Flexible and secure housing alternatives \\
\hline & - Processes that transform the dwelling into a home \\
\hline 2. Basic services (health, education and transport) & $\begin{array}{l}\text { - Basic (public and private) services nearby that facilitate the everyday life } \\
\text { of children }\end{array}$ \\
\hline 3. Participation & - Opportunities to participate in planning and development \\
\hline 4. Safety and security & $\begin{array}{l}\text { - The guaranteeing of physical and psychological safety by the state and } \\
\text { the municipalities: child welfare and the prevention of violence } \\
\text { - An environment which is tolerant and pluralistic } \\
\text { - Safe transport systems and public places in general }\end{array}$ \\
\hline 5. Family, kin, peers and community & - Opportunities for close social relationships with family, kin and friends \\
\hline 6. Urban and environmental qualities & $\begin{array}{l}\text { - High standards in the physical elements of the local environment; } \\
\text { provision of a variety of interesting opportunities and arenas for activities }\end{array}$ \\
\hline 7. Provision and distribution of resources; poverty reduction & $\begin{array}{l}\text { The provision of financial resources and work opportunities to young } \\
\text { people who have a role to play in the local economies }\end{array}$ \\
\hline 8. Ecology & $\begin{array}{l}\text { The protection of nature and the application of the principles of } \\
\text { sustainable development in the construction of the built environment } \\
\text { and the society }\end{array}$ \\
\hline 9. Sense of belonging and continuity & $\begin{array}{l}\text { A sense of cultural continuity and a sense of belonging to a certain } \\
\text { place at a certain time }\end{array}$ \\
\hline 10. Good governance & $\begin{array}{l}\text { A flexible local governance that takes into account young people's } \\
\text { opinions in the decision-making; } \\
\text { - The provision of participatory structures, such as youth councils and } \\
\text { various participatory projects }\end{array}$ \\
\hline
\end{tabular}

tance on green areas because in green areas, they could meet friends and benefit from recreational services.

For Finnish children, natural environment was neither mentioned among the most liked places, nor were of their ideal environment.

In Italy, however, they emphasized the meaning of green areas and placed importance on natural elements. Because green areas enhanced their opportunities to play, have fun and meet friends. ${ }^{36}$

Expressions made by all participants in both Monte Mario and Pihlajamäki, as given in Table 2, are classified by ten dimensions of "environmental child-friendliness" and then evaluated. When participants' replies on physical environment are classified on basis of ten dimensions of environmental child-friendliness (Table 3 ), a physically child friendly environment appears to consist of a neighbourhood unit with low dwellings that are located close to each other; opportunities for independent mobility where one can walk around without any threat of traffic or any risk of danger in social terms; spacious green areas and friends in the vicinity; space for more bicycles and pedestrian paths and places for swimming, but fewer cars; availing for rela-

${ }^{36}$ Haikkola et.al., 2007 tionship with the animals; and a clean environment with no air pollution from cars. These qualities are in parallel to Child Friendly City concept and its objective framework about the design of urban space (such as walking safely in the streets, making friends and playing, having green spaces for plants and animals and living in an unpolluted and sustainable environment).

\section{Case Study From Izmir-Turkey}

In this part, the research conducted in Izmir, Turkey is mainly based on Horelli's definition of "environmental child friendliness" with particular reference to relevant studies held in Europe.

\section{Objectives of the Study and Sample Selection}

The general purpose of the study is to analyze the views of children living in distinctively different districts of Izmir on the concept of "Child Friendly City". Upon this purpose, the study intends to include children in design and planning processes in the long run and provide the most healthy and ideal urban environment for them.

The study has a series of specific purposes under this general purpose. These purposes can be listed as:

i. "To make comparative evaluation of the views of stu- 
Table 3. Normatif dimensions of Child Friendly environment in Pihlajamäki ve Monte Mario (Haikkola et.al., 2007, 339)

\begin{tabular}{|c|c|c|}
\hline Normative dimensions & Pihlajamäki, Helsinki & Monte Mario, Rome \\
\hline 1. Housing and dwelling & $\begin{array}{l}\text { Different kinds of dwellings, not too } \\
\text { tall or ugly buildings }\end{array}$ & Low and small dwellings close to each other \\
\hline $\begin{array}{l}\text { 2. Basic services (health, education and } \\
\text { transport) }\end{array}$ & $\begin{array}{l}\text { Availability of schools, day-care and } \\
\text { youth centres in the vicinity. Good public } \\
\text { transportation, recreational services and } \\
\text { facilities, play/sports }\end{array}$ & $\begin{array}{l}\text { Nearby recreational services and facilities, } \\
\text { good educational services, play/sports }\end{array}$ \\
\hline 3. Participation & $\begin{array}{l}\text { Participation in the Helsinki Voice of } \\
\text { Youth project }\end{array}$ & $\begin{array}{l}\text { Parents' participation in the furnishing of a } \\
\text { play area for children }\end{array}$ \\
\hline 4. Safety and security & $\begin{array}{l}\text { Safety on the streets and in the } \\
\text { shopping centre. Opportunities to move } \\
\text { independently in the neighbourhood. }\end{array}$ & $\begin{array}{l}\text { Opportunities to move independently in the } \\
\text { neighbourhood without risks of car accidents } \\
\text { for children and without risk of dangerous } \\
\text { people for mothers and elderly people. }\end{array}$ \\
\hline 5. Family, kin, peers and community & Friends in the vicinity. & Friends in the vicinity. \\
\hline 6. Urban and environmental qualities & $\begin{array}{l}\text { Spaciousness, green areas, proximity } \\
\text { to school and friends. } \\
\text { A swimming place. }\end{array}$ & $\begin{array}{l}\text { Spacious public spaces and green areas. } \\
\text { A more breathable neighbourhood with less } \\
\text { cars. More bike paths and spacious sidewalks. } \\
\text { Proximity to services and friends. }\end{array}$ \\
\hline $\begin{array}{l}\text { 7. Provision and distribution of } \\
\text { resources; poverty reduction }\end{array}$ & $\begin{array}{l}\text { Financial support to local associations } \\
\text { and community workers. Money to } \\
\text { organize hobbies and clubs. }\end{array}$ & - \\
\hline 8. Ecology & Clean surroundings, no pollution in the air. & $\begin{array}{l}\text { Relationships with animals. } \\
\text { No pollution from cars. }\end{array}$ \\
\hline 9. Sense of belonging and continuity & $\begin{array}{l}\text { Opportunity to live a long time in the area. } \\
\text { Familiarity with the neighbourhood, } \\
\text { its history and its residents. }\end{array}$ & $\begin{array}{l}\text { The neighbourhood as a small town where } \\
\text { the entire community takes care of children, } \\
\text { not just parents. }\end{array}$ \\
\hline 10. Good governance & $\begin{array}{l}\text { Improvement of the shopping centre and } \\
\text { its declining services. }\end{array}$ & $\begin{array}{l}\text { Better equipped recreational services. More } \\
\text { attention to the maintenance of the } \\
\text { neighbourhood. }\end{array}$ \\
\hline
\end{tabular}

dents in private and public schools on the concept of the Child Friendly City"

ii. "To compare the views of children living in districts administrated by municipalities with and without the vision of the Child Friendly City".

In accordance with the first purpose, two different groups took part in the study with 19 and 34 children, with high and low socio-economic opportunities in Gaziemir and Konak districts in Izmir. It is a fact that private schools are amongst the schools preferred by parents with high income level in Turkey. In these schools, it is almost impossible to meet children who do not have social and economic opportunities. The reason for Gaziemir to be chosen as a case study area among plenty of districts is that it does not have any vision related to the Child Friendly City, and lacks any livable spaces for children around the schools.

Due to the heavy traffic, the study area in Gaziemir houses unlivable spaces for children. As the main axis connecting Izmir city center to the airport, Akçay Street acts as an interface between the school and the city. Owing to its heavy traffic, commercial uses appear to be concentrated mostly along this street. Students prefer to spend time mostly in its southwest part surrounded by housing areas. In the north, military zone is takes place at the opposite side of the school close to the Aegean free zone (Figure 1).

The other school displaying low socio-economic data is chosen among neighborhoods with low income level at Konak district. It is inspected that children can use the street as a playground in this neighborhood. ${ }^{37}$ Although the district does not have any claim for becoming a Child Friendly City, just like in Gaziemir, the traffic load is less and there are relatively more livable areas for children in this district (Figure 2).

In order to accomplish the second purpose of the study, Seferihisar is chosen as the case in specific. As a small town located at the southwest part of Izmir with 35.000 inhabitants, Seferihisar does not have much population density

\footnotetext{
${ }^{37}$ Gülay Taşçı, 2010
} 


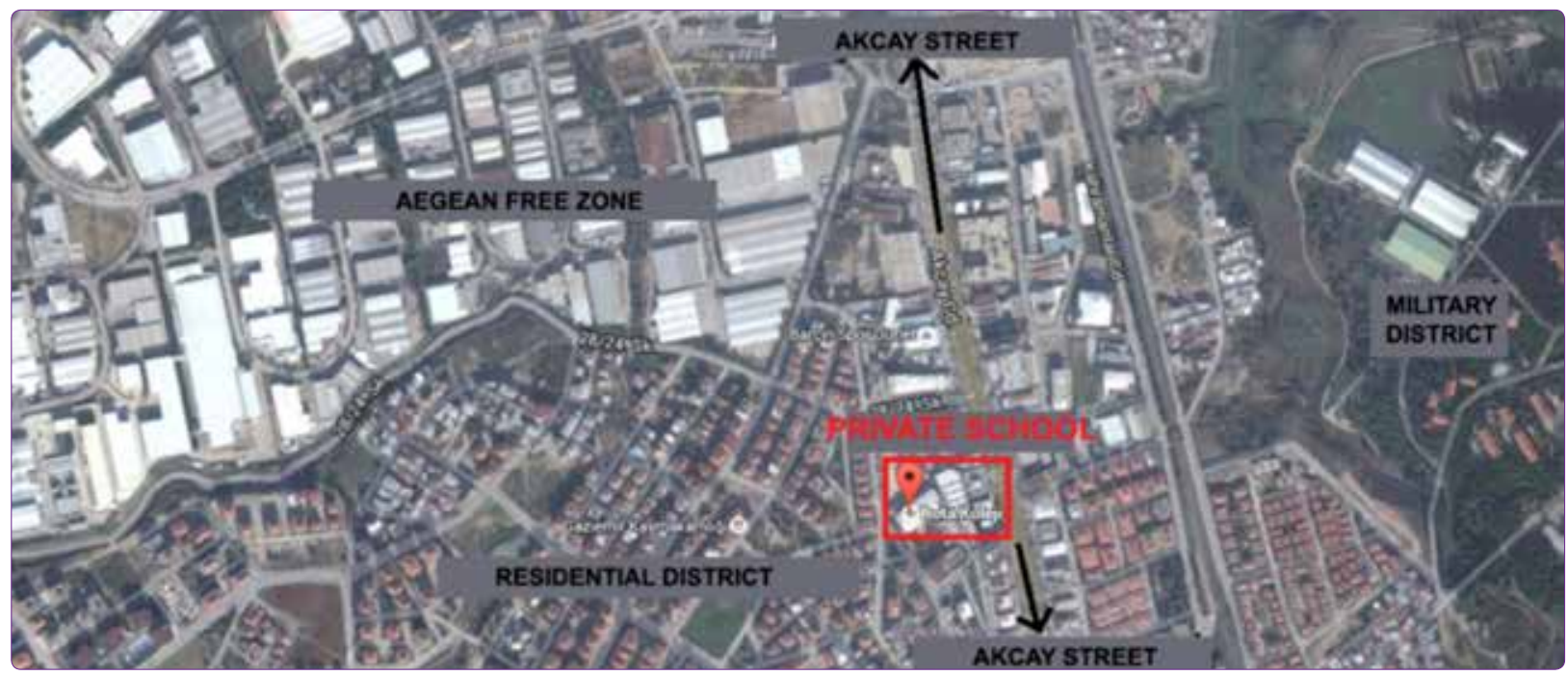

Figure 1. Gaziemir, Case Study, School A (private).

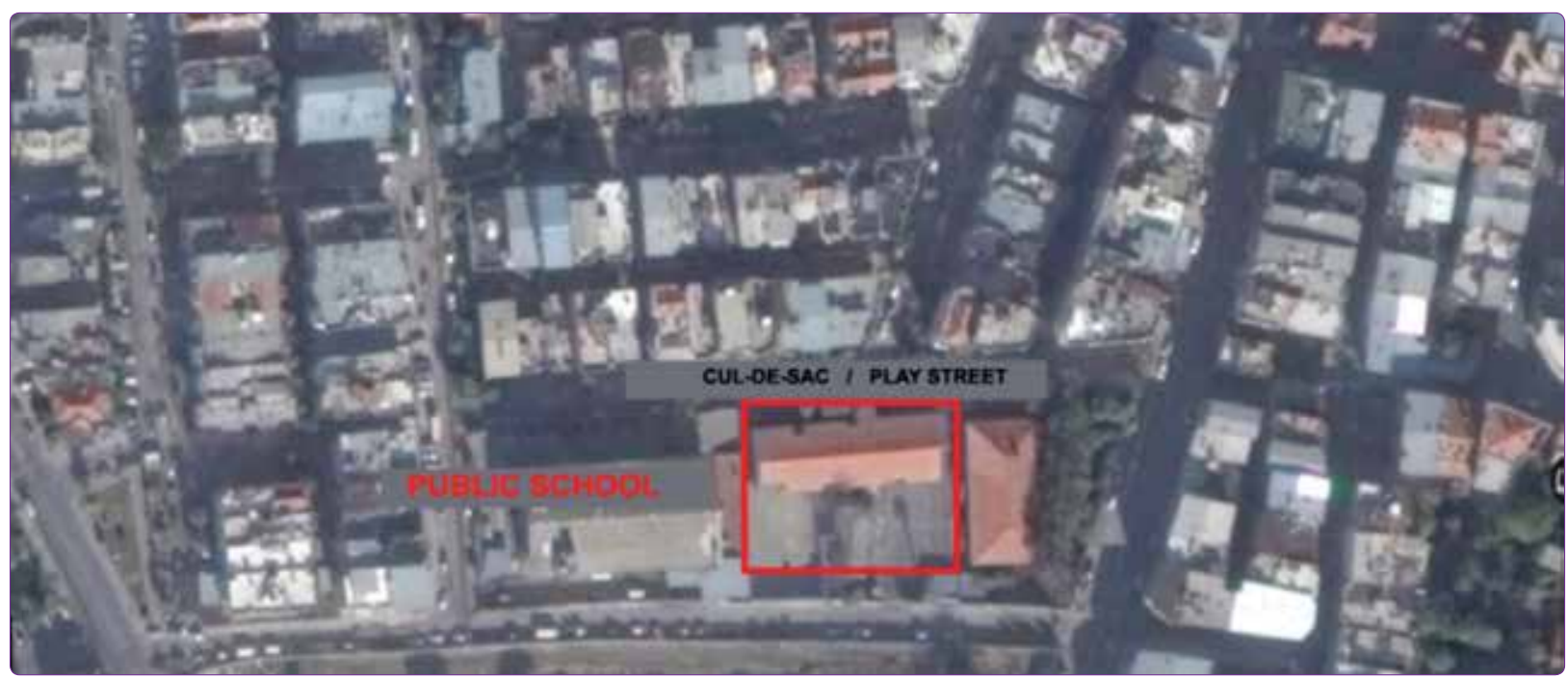

Figure 2. Konak, Case Study Area, School B (public).

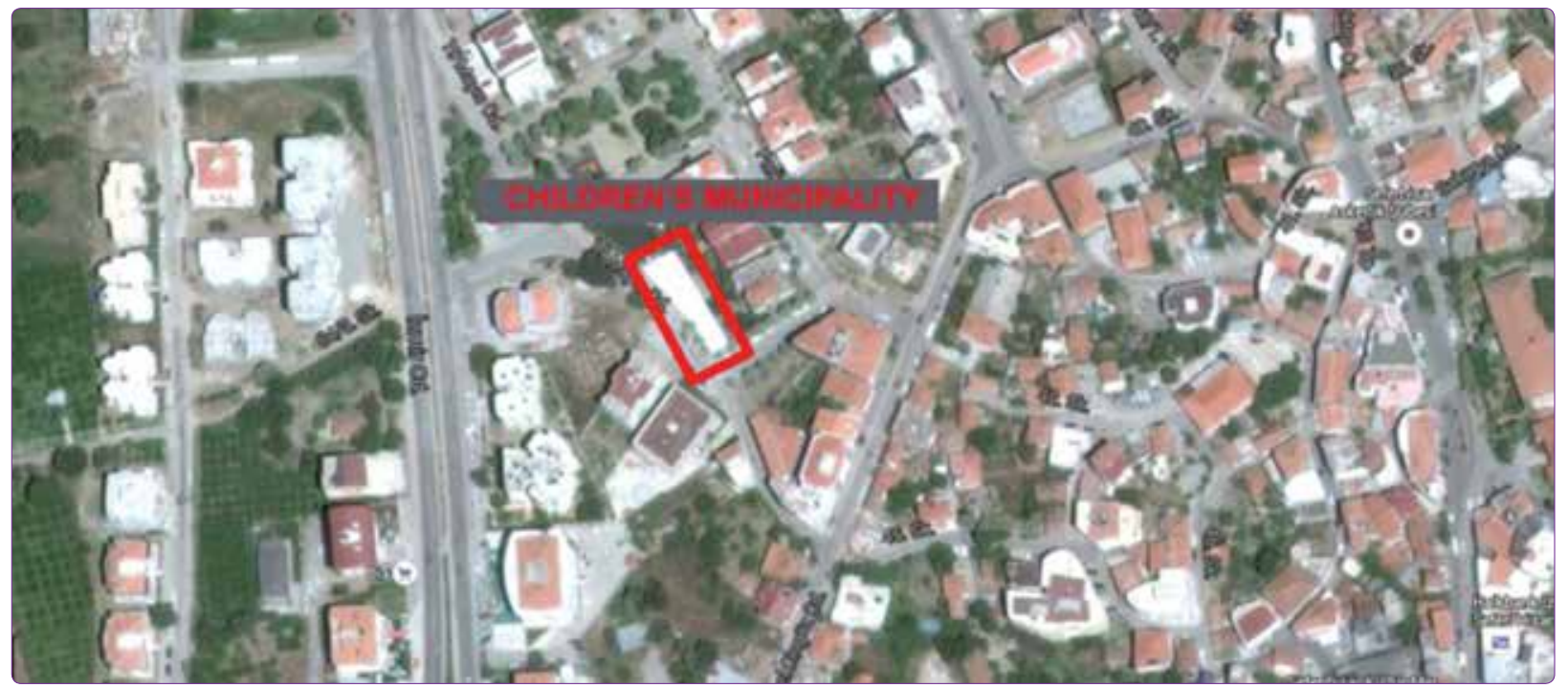

Figure 3. Seferihisar, Case Study Area, Children's Municipality, C. 

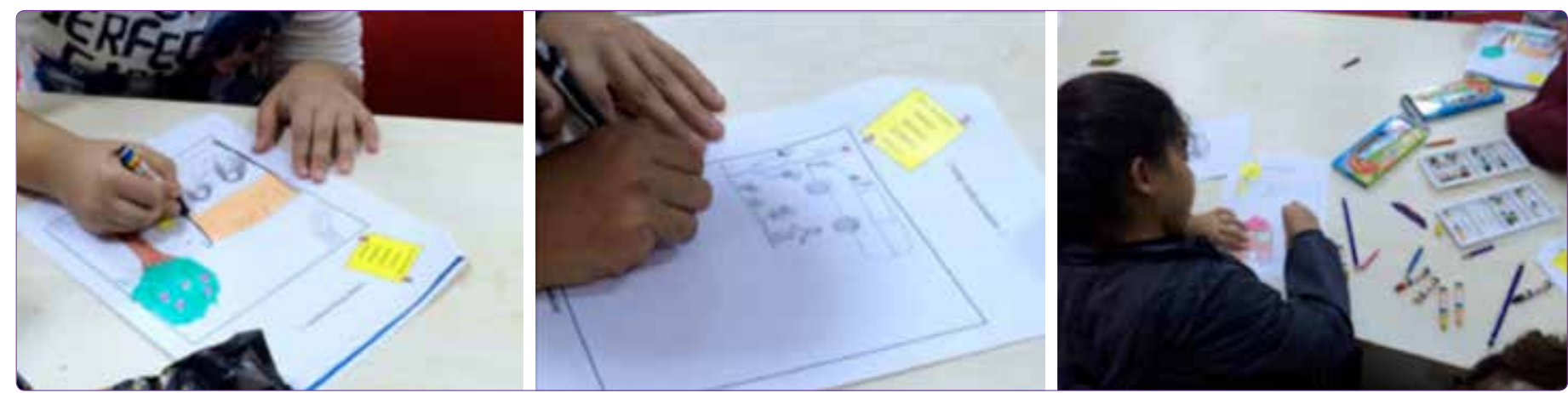

Figure 4. Examples from case study.

Table 4. Views of Children on Child Friendly City by different SED groups

Normative dimensions
Housing and dwelling
Basic services (health, education and transport)
Participation
Safety and security
Family, kin, peers and community
Urban and environmental qualities
Provision and distribution of resources; poverty reduction
Ecology
Sense of belonging and continuity
Good governance

since the size of the settlement is rather large. Seferihisar is labeled as a "Slow City" (Cittaslow) since 2010. Awarding the efforts initiated by Seferihisar Mayor Tunç Soyer, this title is given to Seferihisar by the Cittaslow International Coordination Committee.

Holding the title of a slow city, Seferihisar took the first steps on the subject of Child Friendly urban design. Thanks to this approach, it is claimed that traffic problem, once deemed to affect urban social life significantly, is entirely solved in Seferihisar. As traffic calming is primarily necessary to become a Child Friendly City, it is beneficial to elaborate this claim of being Child Friendly from the eyes of the children.

Therefore, Seferihisar is taken as the case at the last stage of the study. It is questioned whether the municipal works based on the claims of being a Slow City and a Child Friendly City have any impact upon children's views related to the "Child Friendly City" concept. Since it has especially been the children who participated in the urban projects held by the municipality preferred in the study, instead of a random school selection, there were 22 volunteered students from Seferihisar child municipality members chosen (Figure 3).

\section{Tools of Gathering Data}

There were 19 students from Gaziemir, 34 from Konak and 22 from Seferihisar, making up totally 75 volunteered students who provided data for the questionnaire and made relevant drawings as part of their task. At the first page of the questionnaire form, personal information regarding the age, gender and name of the students appeared whereas at the second page, the children were asked to give their opinion concerning a page-long text to the open-ended question of "how the Child Friendly City should be". Further on the last page, the task of drawing the theme "Child Friendly City" took place as an alternative data gathering tool (Figure 4).

As stated by Yavuzer, ${ }^{38}$ the reason for conducting a drawing task is that drawing is an important communication tool to reflect the inner world of children. Drawing is an important tool especially for collecting views of children who cannot sufficiently express themselves in oral and written terms. However, this tool manifests different meanings for each group of age. While the child is in the period of abstract scheming until the age of $9, \mathrm{~s} /$ he enters

\footnotetext{
${ }^{38}$ Yavuzer, 2009.
} 
Table 5. Chidren's views about "child friendly city" concept, Izmir

\begin{tabular}{|c|c|c|c|c|}
\hline & \multirow[b]{2}{*}{ Dimension assessed } & \multicolumn{3}{|c|}{ Indicator expressions (written, oral and drawing) } \\
\hline & & A. Private School (high sed) & B. State school (low sed) & C. (Seferihisar) (med sed) \\
\hline 1 & Housing and dwelling & $\begin{array}{l}\text { Dwellings with technology. } \\
\text { Housing not demolished by } \\
\text { earthquakes... }\end{array}$ & $\begin{array}{l}\text { Small dwellings. } \\
\text { Durable buildings. } \\
\text { Houses easily accessible } \\
\text { with elevators. }\end{array}$ & Where nature friendly houses are built. \\
\hline 2 & $\begin{array}{l}\text { Basic services (health, } \\
\text { education and transport) }\end{array}$ & $\begin{array}{l}\text { More school buildings. } \\
\text { An educative city. } \\
\text { An accessible city without } \\
\text { traffic... }\end{array}$ & $\begin{array}{l}\text { Abundance of schools and } \\
\text { entertainment facilities. } \\
\text { Sports facility areas. } \\
\text { Shopping centers. } \\
\text { Many traffic lights. }\end{array}$ & $\begin{array}{l}\text { Many educational opportunities just } \\
\text { like the children municipality. A livable } \\
\text { city with festivals held along its streets. } \\
\text { A city like Seferihisar with drama } \\
\text { courses, a movie theater and a library. } \\
\text { A clean city with fewer traffic, wide } \\
\text { streets, no problem of transport, } \\
\text { bicycle paths and parking spaces. }\end{array}$ \\
\hline 3 & Participation & - & - & $\begin{array}{l}\text { Decisions taken with the children. } \\
\text { Children have the right to have a say. }\end{array}$ \\
\hline 4 & Safety and security & $\begin{array}{l}\text { A city of peace where no } \\
\text { one kills another... }\end{array}$ & $\begin{array}{l}\text { No robbery. No accidents. } \\
\text { Beautiful roads. Street lights } \\
\text { and illuminated streets. } \\
\text { Safe city. }\end{array}$ & $\begin{array}{l}\text { Many playgrounds. Safe play } \\
\text { equipment fit for the size of children. } \\
\text { Traffic rules obeyed. No accidents. } \\
\text { No violence against children. }\end{array}$ \\
\hline 5 & $\begin{array}{l}\text { Family, kin, peers and } \\
\text { community }\end{array}$ & $\begin{array}{l}\text { A city where I play with } \\
\text { my friends and spend time } \\
\text { with them. Where everybody } \\
\text { is happy together. }\end{array}$ & $\begin{array}{l}\text { Children happy together. } \\
\text { Children playing together. }\end{array}$ & $\begin{array}{l}\text { Peaceful and quiet city. } \\
\text { Everyone is happy. }\end{array}$ \\
\hline 6 & $\begin{array}{l}\text { Urban and environmental } \\
\text { qualities }\end{array}$ & $\begin{array}{l}\text { Plenty of playgrounds. } \\
\text { Special areas for children. } \\
\text { Clean and entertaining. } \\
\text { Everything close to each other. }\end{array}$ & $\begin{array}{l}\text { Playgrounds. } \\
\text { An amusement park. } \\
\text { Colourful. Fun. } \\
\text { Vacant lands. All happy. }\end{array}$ & $\begin{array}{l}\text { More playgrounds. Sports fields. } \\
\text { Gardens. Bicycle paths. Vacant areas. } \\
\text { Zoo. }\end{array}$ \\
\hline 7 & $\begin{array}{l}\text { Provision and distribution } \\
\text { of resources; poverty } \\
\text { reduction }\end{array}$ & $\begin{array}{l}\text { Money trees. } \\
\text { No problem of money. } \\
\text { No poverty. Oil bought not } \\
\text { with money, but love only. }\end{array}$ & $\begin{array}{l}\text { No poverty. } \\
\text { Everything cheap and free. } \\
\text { Free activities. }\end{array}$ & No problem of money. \\
\hline 8 & Ecology & - & $\begin{array}{l}\text { Natural life. } \\
\text { Natural environment. }\end{array}$ & No trees cut down to build houses. \\
\hline 9 & $\begin{array}{l}\text { Sense of belonging } \\
\text { and continuity }\end{array}$ & - & My city. My street. & - \\
\hline 10 & Good governance & - & - & $\begin{array}{l}\text { Children being asked for their ideas. } \\
\text { Where people can protest. } \\
\text { Park for children rights. } \\
\text { Whew children are valuable. }\end{array}$ \\
\hline
\end{tabular}

the period of concrete reality after $s /$ he is 9 . Before $s / h e$ is 9 years old, the child barely makes spatial drawings, but once gets into the reality period, $s /$ he feels him/herself a part of the society. The child's tendency to recognize and reflect his/her environment is high in the period after the age of $9 .{ }^{39}$ Given this, for the act of drawing to be used as a communication tool, the group of age should be specified

\footnotetext{
${ }^{39}$ Gürtuna, 2003
}

according to the context of the drawing and the question. The reason to choose students of age 9-10 for the study focusing on issues of participation is that this age group is in the period of reality and the children feel themselves as individuals belonging to the society.

\section{Findings of the Study}

In the study that was held in Izmir on basis of Horelli's "Child Friendly Environment" definition, the distribution 
of the responses on the "Child Friendly City" concept is given as below:

Interpretation of the quantitative results shows that the different sets of concepts obtained on basis of Horelli's classification are defined differently by children from different districts. Assessment of all SED groups set forth that the focus has mainly been on urban and environmental characteristics, basic services, and safety and security (Table 4). The main points emphasized for the urban and environmental characteristics involved those of playgrounds, sports facilities and bicycle paths. Concerning the basic services, children demanded for more numbers of buildings for education and entertainment and asked for traffic calming in the city. In safety and security terms, children defined child-friendliness as a peaceful city with safe playgrounds and a city where traffic rules are obeyed. In related literature, similar results are common for all similar case studies. In other words, wherever they live in the world, children ask for spaces suited for their rights to become educated and be able to play.

The neglected or less mentioned points are "ecology", "good governance", "participation", "sense of belonging and continuity". As manifest in these responses, there are still problems in Turkey in correlating such issues with child friendly cities. Limited number of students in the Seferihisar group mentioned about "good governance" and "participation". However, when all groups are compared with one another, there appears to be no significant difference concerning the notion of "governance and participation" (Table 5).

Examination of children's drawings indicates that the drawings are in parallel with the written responses. Most children expect the Child Friendly Environments to be green, spacious, clean and well-kept. Another common characteristic of the drawings is the playgrounds. The children expressed their thoughts via drawing amusement

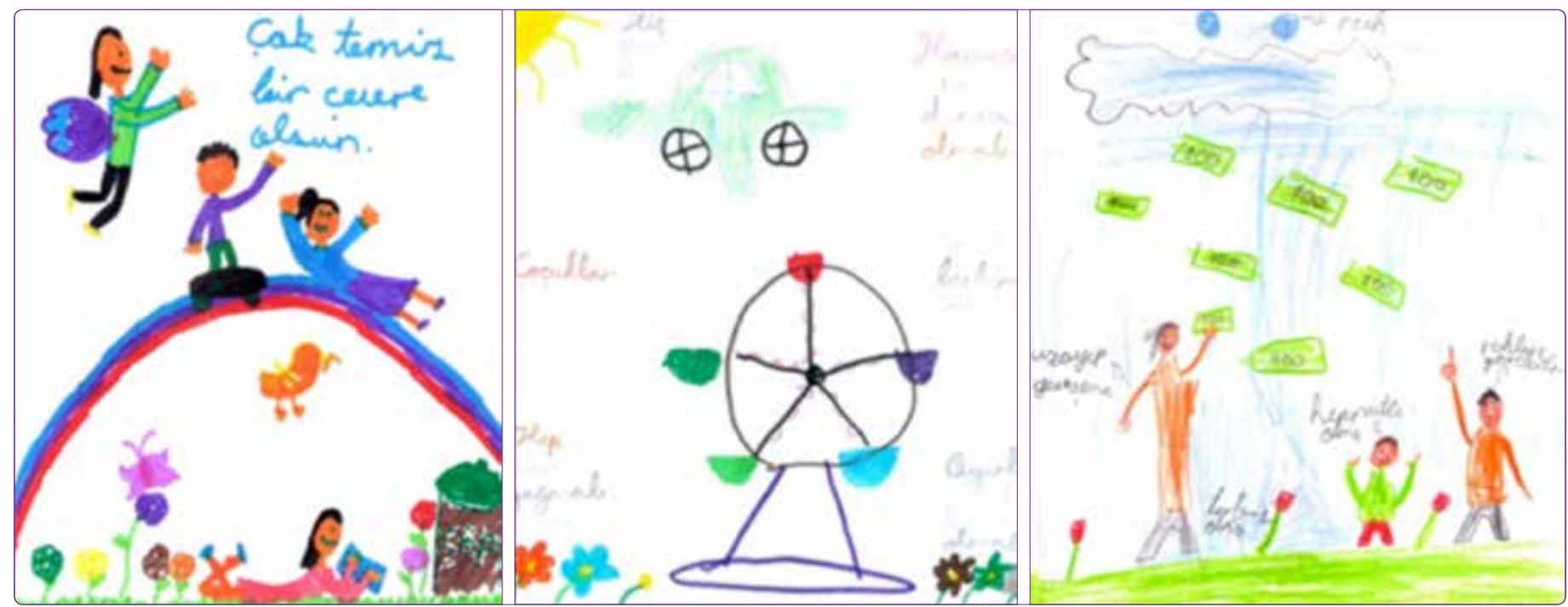

Figure 5. Drawings of children from group A, Gaziemir.
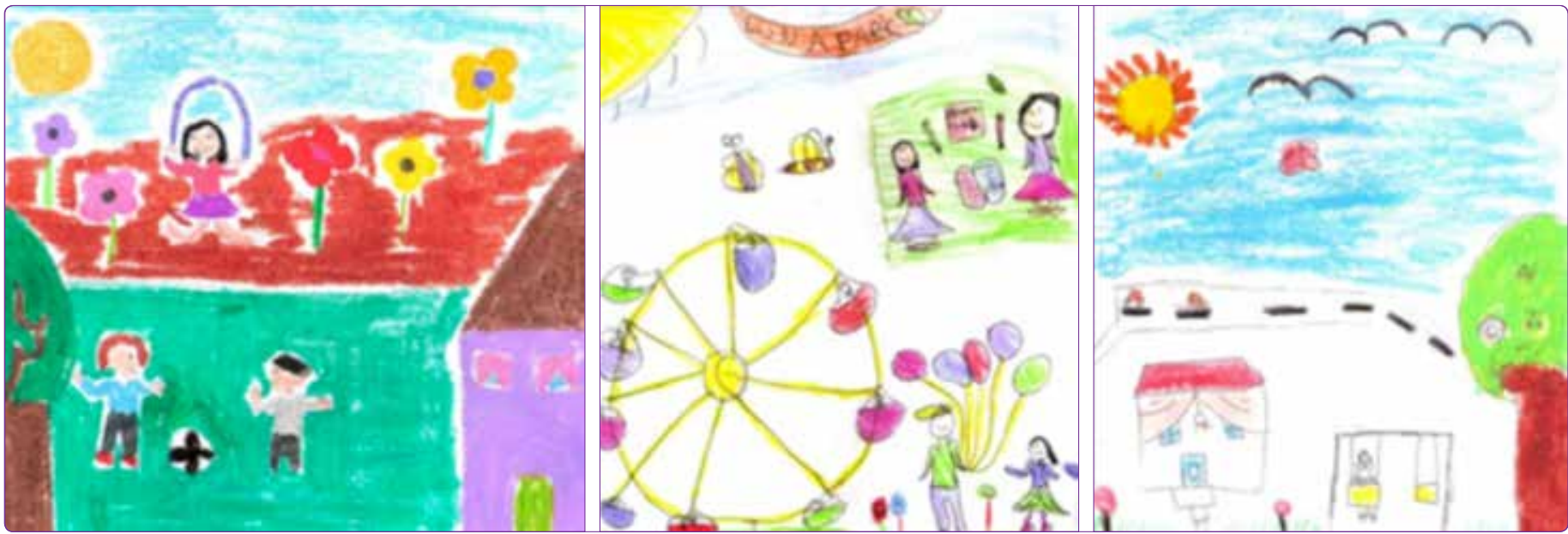

Figure 6. Drawings of children from group B, Konak. 


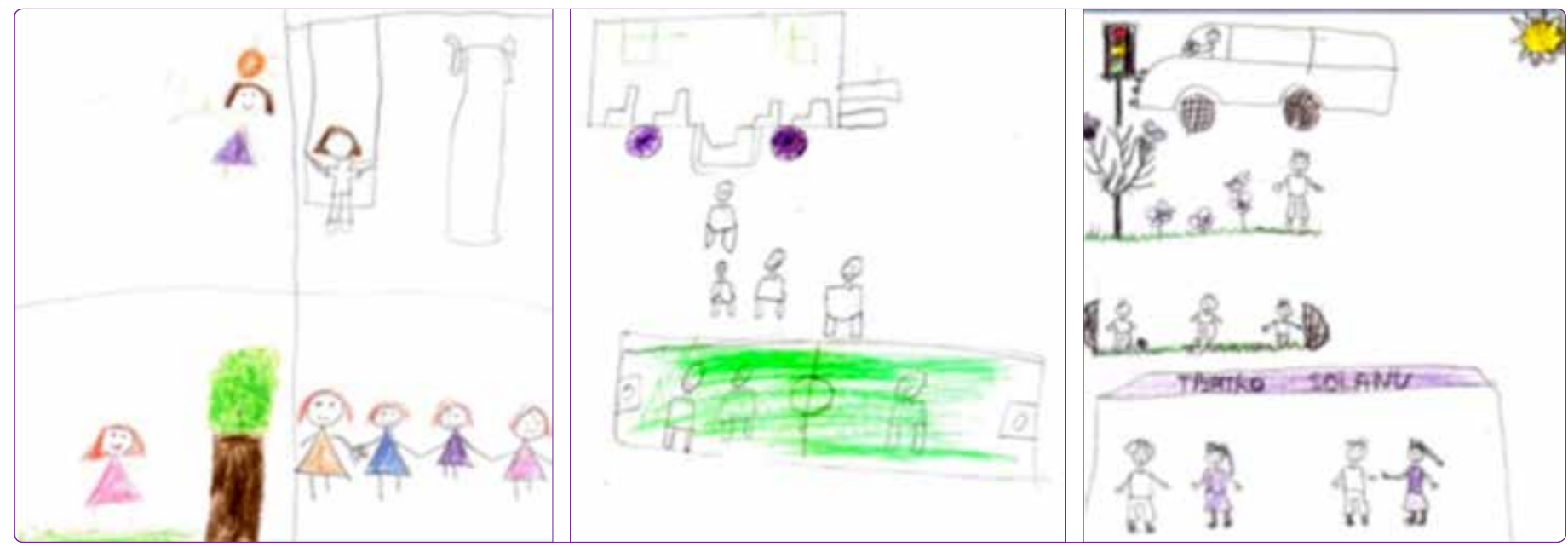

Figure 7. Drawings of children from group C, Seferihisar.

Table 6. Opinion of girls and boys by different socio-economic backgrounds

\begin{tabular}{lll}
\hline & Girls' Opinions (37 students) & Boys' Opinions (38 students) \\
\hline $\begin{array}{ll}\text { A.Private School } \\
\text { (high sed) }\end{array}$ & $\begin{array}{l}\text { A city which is colorful, clean, fun consisting of an } \\
\text { amusement park, water pools, shopping centers, }\end{array}$ & $\begin{array}{l}\text { A city with easy transportation, without any economic } \\
\text { problems (very rich), safe, clean, consisting of playgrounds, } \\
(10 \text { girls })\end{array}$ \\
$\begin{array}{l}\text { flying houses, cars, green gardens, houses with } \\
\text { technology, 30-storeyed play area and houses }\end{array}$ & $\begin{array}{l}\text { fun and music activities, education and green areas; a futurist } \\
\text { city (where robots live and has connections with space etc.); } \\
\text { made up of sugar. A city without gravity. }\end{array}$ & $\begin{array}{l}\text { a city with abundance of opportunities in education facilities } \\
\text { and activities for drama (theater), cinema, festivals etc. and }\end{array}$ \\
& a city which does not have any traffic problem.
\end{tabular}

B.State School A city where houses are small and durable, (low sed)

(17 girls)

(17 boys)

(med sed)

(10 girls)

(12 boys) where there are many schools and entertainment places, without any robbery or accidents, but beautiful streets, with playgrounds and amusements parks where happy children play together; a city which is colorful, clean and without poverty, where everyone is happy and everything is cheap.

A city with abundance of opportunities for education facilities and offering activities for drama (theater), cinema, festivals, etc. A city which does not have any traffic problem.
A city which is clean and has many playgrounds, more numbers of sports facilities, football fields, where transport is safe without any traffic accidents and where everyone is happy.

A city with abundance of opportunities for education facilities and offering activities for drama (theater), cinema, festivals, etc. A city which does not have any traffic problem. parks, sports facilities, and playgrounds. The children also demand to see different social amenities such as theater and cinema around. A different set of expressions are commonplace rather for private school students who put an emphasis on "technology and economic power" in almost all their demands (Figure 5-7).

Analysis of the children's Child Friendly City definition in terms of SED and gender reveals that there is no difference between the students' definitions in the middle SED group. Male and female students gave similar definitions. Emphasis of male students in the high and low
SED on the lack of sports activities is remarkable. Table 6 shows that the children's first point of emphasis regarding the Child Friendly City pertains to the playgrounds. The most important reason underlying this response is that playgrounds, as encountering the basic needs of children, do not fulfill the demands since they apparently lack any quality, let alone the insufficient number of playgrounds provided.

\section{Conclusion}

This study intends to draw a framework for the issue of 
"Child Friendly City" by examining Horelli's study ${ }^{40}$ and the research held thereafter. The field study reveals the views of children from different districts on the "Child Friendly City" concept. The obtained results sets forth that there are many common points drawn out from responses of the private school and public school students on the "Child Friendly City" concept, thus socio-economic data do not cause any significant difference in the opinion of children. Analysis of the common points emphasized by all children is as given below:

1. The children think that the "Child Friendly Cities" shelter durable and environment-friendly dwellings with less stories, and areas easy to move and play, therein having no risks in terms of traffic in their immediate environment.

2. Another essential point about "Child Friendly Cities" pertains to the existence of educational facilities, open playgrounds and sports facilities in the immediate environment of housing. These two characteristics are in parallel with the objectives of urban design regarding the "Child Friendly City" concept.

3. Children consider living in safe environments highly important if freed from negative effects of traffic and crowds of people.

4. Taking the views of children about urban implementations and giving them the right to speak on the related issues are also emphasized. Children demand to have platforms where they can express themselves. In their opinion, decisions related the children fail in application and the facilitators remain far more insufficient on such issues.

5. The children regard places as child friendly only if they have colorful, enjoyable and clean playgrounds and bicycle paths where they can be with their friends in peace. They also correlate the development of the sufficient Child Friendly Environments with economic conditions (wealth, absence of poverty).

Another result obtained is that children's perception on the Child Friendly City is similar at both districts, with no difference whether there have been specific projects held for the same purpose or not. As a matter of fact, this result does not address to any desired circumstance at all. This manifests that the studies held in Seferihisar district are not comprehended well -by the children and that the sense of participation cannot become an intrinsic process for urban matters. Departing from this point, one can argue that the municipalities shall indeed review and increase their participation-oriented studies within a pragmatist approach. Nevertheless, the points to be taken into consideration here is how participation shall be en-

\footnotetext{
${ }^{40}$ Horelli, 1998.
}

couraged and how the Child Friendly City issue shall be approached with a model involving children. Considering the inadequacy of the implementations in Turkey, the necessity to draw attention to political processes is evidently to be disclosed for future studies.

In conclusion, this study shows that the studies about "Child Friendly Cities" in the world and in Turkey are in parallel. The understanding and demands of children for a Child Friendly City remain similar all around the world. Creation of proper places for children shall not be confined to construction of playgrounds merely, but should be nourished with the vision and understanding that. The Child Friendly City should foster environment-friendly, clean and safe places and that local governments should give place to the voice of children in their practice. Such studies held with and for children points out that, children can think and have a voice about their cities, and provide crucial data for local governments. By way of involving children in design and planning processes, such studies promise to develop the healthiest ideal urban setting for many generations in the long run.

\section{References}

Ayataç, H. and Genç, Z. P. (2015) “Çocuk Gözüyle Esenler”, Herkes İçin Dost Esenler, ed: Doç. Dr. Hatice Ayataş, Esenler Belediyesi, Şehir Düşünce Merkezi, Şehir Yayınları, İstanbul, 18-57.

Bartlett, S. (2002) "Building Better Cities with Children and Youth" Environment and Urbanization, 14(2), s. 3-10. www. eau.sagepub.com, [Date accessed 27.8.2014]

Birol, G. (2009) "Çocuk Dostu Kent Neresidir?", Megaron Balıkesir Mimarlar Odası Dergisi, Ocak, 10-13.

Björklid, P. and Nordström, M. (2007) "Environmental Child Friendliness: Collaboration and Future Research", Children, Youth and Environments, 17(4), s. 388-401.

Cele, S. (2006) "Communicating Place: Methods for Understanding Children's Experience of Place", Dissertation, Department of Human Geography, Stockholm University.

Chawla, L. (1997) "Growing up in Cities: a Report on Research Under Way" Environment and Urbanization, 9(2), s.247-251. www.eau.sagepub.com, [Date accessed 3.7.2013]

Gökmen, H. S. (2008) "Çocuk Dostu Kentler Oluşturmak", Mimarist, 8(28), 49-54.

Gökmen, H. (2013) "Çocuk Dostu Kent Üzerine Stratejiler", TMMOB. 2. İzmir Kent Sempozyumu, 28-30 Kasım 2013, İzmir; Bildiriler Kitabı, 819-827.

Gökmen, H. S. and Taş̧ı, B. G. (2011) "Çocuk Dostu Mekanlar Oluşturma Konusuna Bir Başlangıç", 1. Türkiye Çocuk Hakları Kongresi - Yetişkin Bildiriler Kitabı-1, 25-27 Şubat 2011, Çocuk Vakfi Yayınları, Yayına Hazırlayan: Prof. Dr. A. Gülan, M. R. Şirin, M. C. Şirin, İstanbul, 433-450.

Gülay Taş̧ıı, B. (2010) "Sokağın Günümüz Koşullarında Oyun Alanı Olarak Ele Alınması ve Değerlendirilmesi", Yüksek Lisans Tezi, Dokuz Eylül Üniversitesi, Fen Bilimleri Enstitüsü.

Güngör, H. (2002) Tarlabaşı Bölgesinde Yaşayan Çocukların Çevrelerini Algılaması ve Değerlendirmesi, Yayınlanmamış Yüksek Lisans Tezi, iTÜ. FBE. 
Gürtuna, S. (2003) Çocuk ve Sanat Eğitimi. Istanbul: Morpa Kültür Yayınları.

Hart, Roger (1992) Children's Participation from Tokenism to Citizenship. Innocenti Essays, Florence: UNICEF.

Haikkola, L.; Pacilli, M. G.; Horelli, L. and Prezza, M. (2007) “Interpretations of Urban Child-Friendliness: A Comparative Study of Two Neighborhoods in Helsinki and Rome", Children, Youth and Environments, 17(4), s. 319-351.

Holloway, S. and Valentine, G. (2000) "Children's Geographies and the New Social Studies of Childhood.", In Holloway, S. and Valentine, G. eds. Children's Geographies: Playing Living Learning. London and New York: Routledge, s. 1-26.

Horelli, L. (1998) "Creating Child-Friendly Environments, Case Studies on Children's Participation in Three European Countries", Childhood, 5(2), s. 225-239.

Horelli, L. (2007) "Constructing a Theoretical Framework for Environmental Child-Friendliness", Children, Youth and Environments, 17(4), s. 267-292.

Karsten, L. (2005) "It All Used to be Better? Different Generations on Continuity and Change in Urban Children's Daily Use of Space", Children's Geographies, 3(3), s. 275-290.

Kirazoğlu, F. S. (2012) Fiziksel Çevre-Çocuk illişkileri, Açık Oyun Mekanları ve Çocuk Dostu Çevre Kriterleri Üzerine Bir Değerlendirme: Bakırköy ve Beylikdüzü Örnekleri, Yayınlanmamış Yüksek Lisans Tezi, iTÜ. FBE.

Kirazoğlu, F. S. \& i. Akpınar (2015) "Children Psychology and Outdoor Play Areas in İstanbul: Bakırköy and Beylikdüzü Cases, ITUA/Z, 12(1), 107-114, http://www.az.itu.edu.tr/azvol12no1web/11-\%20kirazoglu_akpinar-1201.htm, [Date accessed 5.4.2015]

Koç, N., Tavşancıl, E. and Demir, E. (2015) "Çocuk Dostu Şehir Girişimi ve Çocukların Gözüyle Ankara”, İdealkent, 17, Eylül, 106-139.

Malone, K. (2006) "United Nations: A key player in global movement for child friendly cities" In B. Gleeson \& N. Sipe, eds. Creating Child Friendly Cities: Reinstating Kids in the City. Abingdon, UK.: Routledge,s. 13-32. www.academia.edu/393069/, [Date accessed 28.10.2013]

Mc. Kendrick, J., Bradford M. and Fielder, A. (2000) "Kid Customer? Commercialization of Play Space and the Commodificiation of Childhood", Childhood, 7(3), s.295-314.

Moore, R. (1990) Childhood's Domain Play and Place in Child Development, Berkeley CA: MIG Communications.

Özservet, Y. Ç. and Boz, S. (2015) "Çocuk Dostu Esenler ve Yerel Yönetim Illişkisi", Herkes İçin Dost Esenler, ed: Doç. Dr. Hatice Ayataş, Esenler Belediyesi, Şehir Düşünce Merkezi, Şehir Yayınları, İstanbul, 86-115.

Özservet, Y. Ç. (2016) "Çocuğa Dost Bir Adana Kenti İçin", Kentlerimizin Yaşam Kalitesi ve Adana, Panel, ed: Bülend Tuna, TMMOB. Mimarlar Odası Adana Şubesi ve Mimarlık Vakfi İktisadi işletmesi, Adana, 65-82.

Prezza, M. (2007) “Children's Independent Mobility: A Review of
Recent Italian Literature", Children, Youth and Environments, 17(4), s. 293-318. http://www.colorado.edu/journals/, [Date accessed 16.12.2014]

Riggio, E. (2002) "Child Friendly Cities: Good Governance in the Best Interests of the Child", Environment and Urbanization, 14(2), s. 45-58 www.eau.sagepub.com, [Date accessed 3.8.2014]

Rissotto, A. and Giuliani, M. V. (2006) "Learning Neighborhood Environments: The Loss of Experience in a Modern World" In Spencer, C. and M. Blades, eds. Children and Their Environments: Learning, Using and Designing Spaces, Cambridge University Press, s.75-90.

Risotto, A. and Tounucci, F. (2002) "Freedom of Movement and Environmental Knowledge in Elementary School Children", Journal of Environmental Psychology, 22, s. 65-77.

Severcan, Y. C. (2015) “Çocukların Gözünden Çocuk dostu Yer Kavramı ve Yaşanılan Çevrelerin Değerlendirilmesi: İstanbul Örneği”, İdealkent, 17, Eylül, 140-181.

Spencer, C. and Woolley, H. (2000) "Children and the City: A Summary of Recent Environmental Psychology Research", Child: Care, Health and Development, 26(3), s. 181-198.

Tandoğan, O. (2011). İstanbul'da "Çocuk Dostu Kent" İçin Açık Alanların Planlama, Tasarım ve Yönetim illkelerinin Oluşturulması, Yayınlanmamış Doktora Tezi, iTÜ. FBE.

Tandoğan, O. (2014) "Çocuk için Daha Yaşanabilir Bir Kentsel Mekan: Dünya'da Gerçekleştirilen Uygulamalar", Megaron, 9(1), 19-33, http://www.journalagent.com/megaron/pdfs/ MEGARON-43534-ARTICLE-TANDOGAN.pdf, [Date accessed 9.4.2014]

Tandoğan, O. (2015) "Şehirde Çocuk", Çocukların Şehri Üzerine, eds: Y. Ç. Özservet ve E. Küçük, Marmara Belediyeler Birliği, Kültür Yayınları, Yayın No: 91, İstanbul, 66-94

Tandoğan, O. and N. Ergun (2013a) "Assessment of the ChildFriendliness of the Küçük Ayasofya Neighborhood in Istanbul, Turkey", Children, Youth and Environments 23(3): 164-183, https://www.academia.edu/, [Date accessed 25.4.2016]

Tandoğan, O. and Ergun, N. (2013b). "Çocuk İçin Daha Yaşanabilir Bir İstanbul İçin Öneriler: Başakşehir Kiptaş Toplu Konut ve Küçük Ayasofya Mahallesi Örneği”, Planlama, 23(3), 134-146.

Ter, Ü. (2015) "Çocuklara Dost Kentsel Dış Mekan ve Tasarımı", Çocukların Şehri Üzerine, eds: Y. Ç. Özservet ve E. Küçük, Marmara Belediyeler Birliği, Kültür Yayınları, Yayın No: 91, İstanbul, 203-215.

UNICEF (2004a) Building Child Friendly Cities A Framework for Action, www.childfrienlycities.org, [Date accessed 9.10.2013]

UNICEF (2004b) Çocuk Haklarına Dair Sözleşme, www.unicef. org/turkey, [Date accessed 15.5.2008].

Yavuzer, H. (2009). Resimleriyle Çocuk. Istanbul: Remzi Kitabevi. www.childinthecity.com, [Date accessed 15.5.2008] www.ozgeder.org.tr [Date accessed 12.03.2008] www.unicef.org/turkey, [Date accessed 9.10.2013] 